
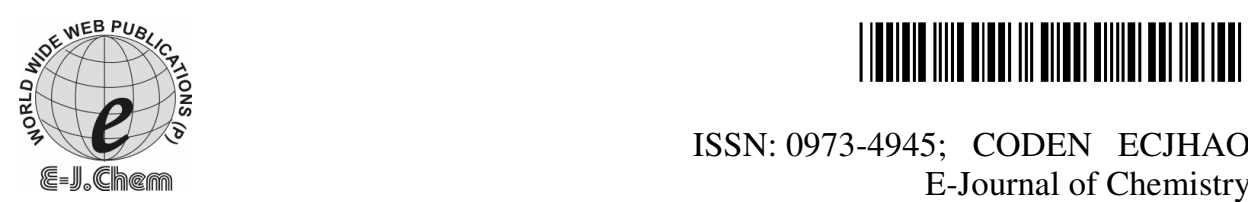

ISSN: 0973-4945; CODEN ECJHAO

http://www.e-journals.net

E-Journal of Chemistry 2009, 6(2), 489-494

\title{
Determination of Pantoprazole Sodium and Lansoprazole in Individual Tablet Dosage Forms by RP-HPLC Using Single Mobile Phase
}

\author{
B. PRASANNA KUMAR REDDY*, \\ Y. RAMANJANEYA REDDY and D. RAMACHANDRAN \\ *Department of Quality Control and Analytical Research and Development, \\ Smilax Laboratories Limited, Jeedimetla, Hyderabad-500055, A.P, India. \\ Department of Chemistry and Biochemistry, ANU Campus, Nuzvid-521201, A.P, India. \\ drbpkreddy@gmail.com
}

Received 7 September 2008; Accepted 10 October 2008

\begin{abstract}
A simple, sensitive and precise high performance liquid chromatographic method for the analysis of pantoprazole sodium and lansoprazole has been developed, validated and used for the determination of compounds in commercial pharmaceutical products. The compounds were well separated an isocratically on a $\mathrm{C}_{18}$ column [Inertsil $\mathrm{C}_{18}, 5 \mu, 150 \mathrm{~mm} \times 4.6 \mathrm{~mm}$ ] utilizing a mobile phase consisting of acetonitrile: phosphate buffer $(60: 40$, $\mathrm{v} / \mathrm{v}, \mathrm{pH} 7.0$ ) at a flow rate of $1.0 \mathrm{~mL} / \mathrm{min}$ with UV detection at $230 \mathrm{~nm}$. The retention time of pantoprazole sodium and lansoprazole was found to be $2.017 \mathrm{~min}$ and 2.538 . The procedure was validated for linearity (Correlation coefficient $=0.999)$. The study showed that reversed-phase liquid chromatography is sensitive and selective for the determination of pantoprazole sodium and lansoprazole using single mobile phase.
\end{abstract}

Keywards: Pantoprazole sodium, Lansoprazole, RP-HPLC, Method validation and Tablets

\section{Introduction}

The proton-pump inhibitor pantoprazole sodium inhibit gastric acid by blocking the $\mathrm{H}^{+} / \mathrm{K}^{+}$adenosine triphosphatase enzyme system (the proton pump) of the gastric parietal cell ${ }^{1}$. It is used for short-term treatment of erosion and ulceration of the esophagus ${ }^{2}$. The pantoprazole sodium oral dosage forms are supplied in enteric-coated tablets. Different analytical methods are reported in the literature for the assay of pantoprazole sodium in dosage forms and in biological fluids including spectrophotometry ${ }^{3-8}$, TLC $^{9}$, HPTLC $^{10-12}$. Pantoprazole sodium is chemically sodium 5-(difluoromethoxy)-2-[[(3, 4-dimethoxy-2-pyridinyl) methyl] sulfinyl]$1 H$-benzimidazole sesquihydrate. Lansoprazole ${ }^{13}$ is chemically $2-(\{3-$ methyl-4- $(2,2,2-$ trifluoroethoxy)-2-pyridyl) methyl $\}$ sulfinyl benzimidazole, is used as a gastric proton pump 
inhibitor. It has an empirical formula of $\mathrm{C}_{16} \mathrm{H}_{14} \mathrm{~F}_{3} \mathrm{~N}_{3} \mathrm{O}_{2} \mathrm{~S}$ and a molecular weight of 369.36 . Literature survey revealed HPTLC, spectrophotometric and spectrofluorometric methods for determination of lansoprazole in bulk, dosage forms, biological fluids and acid-induced degradation studies ${ }^{14-17}$

\section{Experimental}

A High Performance Liquid Chromatograph system, with LC solutions data handling system (Shimadzu-LC 2010) with an auto sampler was used for the analysis. The data was recorded using LC 2010 solutions software. The purity determination performed on a stainless steel column $150 \mathrm{~mm}$ long, $4.6 \mathrm{~mm}$ internal diameter filled with octadecyl silane chemically bonded to porous silica particles of $5 \mu \mathrm{m}$ diameter (Inertsil $\mathrm{C}_{18}, 5 \mu, 150 \mathrm{~mm} \times 4.6 \mathrm{~mm}$, make: Shimadzu ltd, Japan) with the mobile phase containing acetonitrile and phosphate buffer in the ratio of $60: 40(v / v \mathrm{pH} \mathrm{7.0)}$ at ambient temperature. Flow rate was kept at $0.8 \mathrm{~mL} / \mathrm{min}$, and the elution was monitored at $260 \mathrm{~nm}$.

\section{Reagents and chemicals}

Pantoprazole sodium and lansoprazole working standard were used from Smilax Laboratories Limited. For the estimation of pantoprazole sodium and lansoprazole in bulk and commercial formulations of lansoprazole brand (Pantin-20, Genex laboratories LAN, Intas laboratories), 20 tablets were obtained from retail pharmacies. Each tablet was labeled contain $20 \mathrm{mg}$ of pantoprazole sodium and $30 \mathrm{mg}$ of lansoprazole and had an expiry of not less than 365 days at the time of study. HPLC grade sodium dihydrogen phosphate $\left(\mathrm{NaH}_{2} \mathrm{PO}_{4}\right)$, disodium hydrogen phosphate $\left(\mathrm{Na}_{2} \mathrm{HPO}_{4}\right)$ and acetonitrile procured from Merck, India. High pure water was prepared by using Millipore Milli Q plus purification system.

\section{Preparation of mobile phase}

Mobile phase was prepared by mixing $700 \mathrm{~mL}$ of acetonitrile with $300 \mathrm{~mL}$ of phosphate buffer and its $\mathrm{pH}$ adjusted to 7.0. The mobile phase was sonicated for $15 \mathrm{~min}$ and then it was filtered through a $0.45 \mu$ membrane filter paper.

\section{Preparation of stock and standard solutions}

Accurately weighed $25 \mathrm{mg}$ of test sample taken into a clean dry $50 \mathrm{~mL}$ volumetric flask, dissolved and diluted to the mark with mobile phase. This solution was marked as sample solution. This solution contains $0.5 \mathrm{mg} / \mathrm{mL}$ of sample. Qualified working standard of pantoprazole sodium and lansoprazole was used to carry out validation exercise. The potency of working standard was $99.78 \%$ and $99.85 \%$. With the optimized chromatographic conditions, a steady baseline was recorded, the standard solution was injected and the chromatogram was recorded. This procedure was repeated to sample preparation.

\section{Assay in formulations}

In case of marketed formulations, five accurately weighed tablets were crushed to a fine powder and an amount equivalent to $10 \mathrm{mg}$ of pantoprazole sodium and lansoprazole was added into different $100 \mathrm{~mL}$ volumetric flasks and volume was made up with acetonitrile and methanol mixture. The samples were filtered through a $0.45 \mu \mathrm{m}$ membrane filter, different serial dilutions $(3.10,6.20,12.40,25 \mu \mathrm{g} / \mathrm{mL})$ were made from this solution in $25 \mathrm{~mL}$ volumetric flask and were injected for HPLC analysis. The retention time of pantoprazole sodium and lansoprazole was found to be $2.017 \mathrm{~min}$ and 2.538 (Figure 1 and Figure 2). 


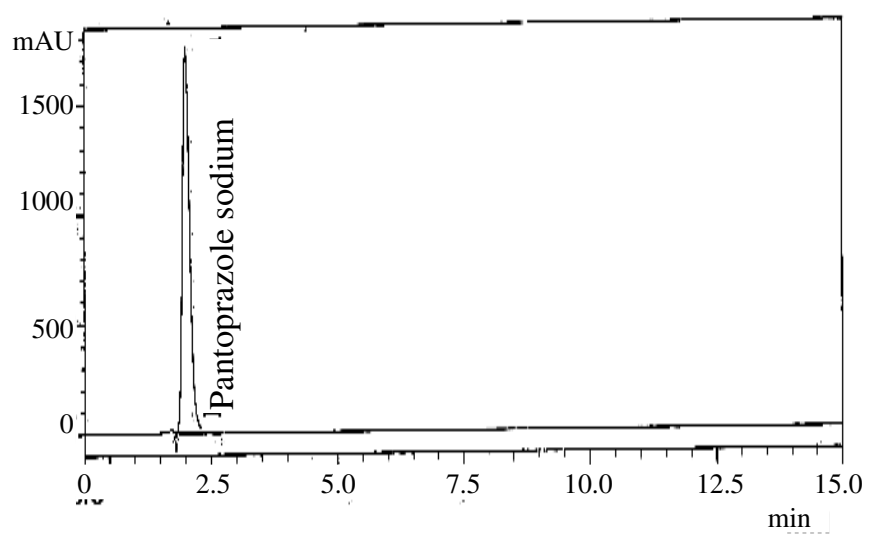

Figure 1. Chromatogram of pantoprazole sodium.

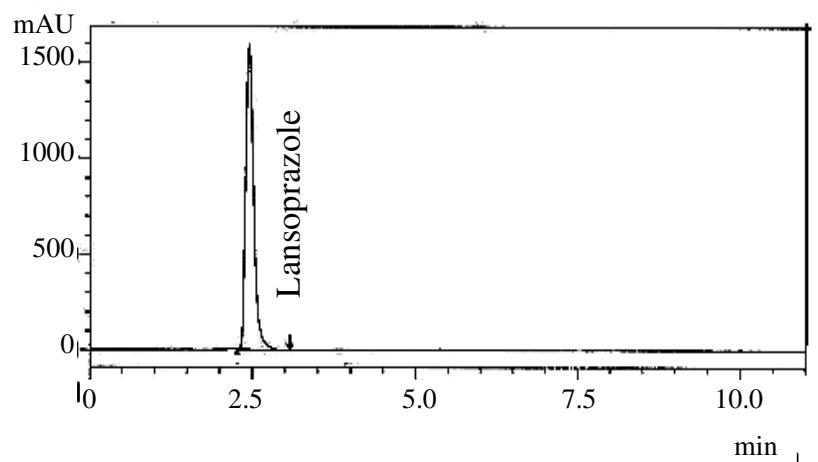

\section{Method validation}

Figure 2. Chromatogram of lansoprazole.

The method was validated for the parameters like specificity, range and linearity, limit of detection (LOD), limit of quantitation (LOQ), accuracy and precision. In addition, system suitability parameters were also calculated. To demonstrate specificity in the presence of excipients used in formulation, pantoprazole sodium was spiked (at approximately $25 \mu \mathrm{g} / \mathrm{mL}$ ) in drug product, chromatogram was observed and compared with that of raw material. To evaluate the linearity, the LOD and LOQ of the method in reference drug, different serial dilutions $(0.0980,0.180,0.80,1.50,3.10,6.30,12.50$ and $25 \mu \mathrm{g} / \mathrm{mL})$ were prepared from the standard stock solutions of pantoprazole sodium and lansoprazole in $25 \mathrm{~mL}$ volumetric flasks and volume made up with diluent which is mixture of 60:40 acetonitrile \& methanol. The samples were injected $(10 \mu \mathrm{L})$ and signals from the samples were recorded which were compared with those of blank. LOD and LOQ values were calculated as signal-to-noise ratio of 3:1 and 10:1 respectively. To determine accuracy of the method, working standard of pantoprazole sodium was prepared in triplicate at three concentration levels (10, 20 and 25 $\mu \mathrm{g} / \mathrm{mL}$ ) and analyzed. Repeatability of the method was checked by analyzing six replicate samples of pantoprazole sodium (at the $100 \%$ concentration level) and calculating relative standard deviation (\%RSD). To determine intermediate precision, standard solutions of pantoprazole sodium and lansoprazole at eight concentration levels were analyzed three times within the same day (intra-day variation) and three other days (inter-day variation). 


\section{Results and Discussion}

\section{System suitability}

The HPLC system was equilibrated with the initial mobile phase composition followed by 10 injections of the same standard. These 10 consecutive injections were used to evaluate the system suitability on each day of method validation. The system suitability parameters including capacity factor $>2$, resolution $>3$ and asymmetric factor $<2$. All parameters were satisfactory with good specificity for the stability assessment of pantoprazole sodium and lansoprazole. Theoretical plates of the column were $>3000$.

\section{Accuracy}

The accuracy of an analytical method is the closeness of test results obtained by that method to true value. In case of the assay of a drug in a formulated product, accuracy may be determined by application of the analytical method to synthetic mixtures of the drug product components to which known amount of analyte has been added within the range of method. If it is not possible to obtain samples of all drug product components, it may be acceptable to add known quantities of the analyte to the drug product (i.e."to spike"). In our studies, the later technique was adopted and pantoprazole sodium was spiked in drug product. The result of accuracy (Table 1) revealed that the method was found accurate for all above purposes.

Table 1. Accuracy/recovery of pantoprazole sodium and lansoprazole.

\begin{tabular}{cccc}
\hline Parameters & Conc., $\mu \mathrm{g} / \mathrm{mL}$ & $\begin{array}{c}\text { \% Recovery of } \\
\text { pantoprazole sodium }\end{array}$ & $\begin{array}{c}\text { \% Recovery of } \\
\text { lansoprazole }\end{array}$ \\
\hline Assay & 10 & 96 & 97 \\
(Spiking & 20 & 101.50 & 101.60 \\
method) & 25 & 95.10 & 95.20 \\
& 6.30 & 99.10 & 99.18 \\
Assay & 12.40 & 100 & 100 \\
& 25 & 99.98 & 99.99 \\
\hline
\end{tabular}

\section{Precision}

Precision is the degree of reproducibility or repeatability of the analytical method under normal operating conditions. The method passed the test for repeatability as determined by \%RSD of the area of the peaks of six replicate injections at $100 \%$ test concentration. The results of intraand inter-day variation of pantoprazole sodium and lansoprazole were shown in Table 2.

Table 2. Intermediate precision of the method.

\begin{tabular}{ccccc}
\hline \multirow{2}{*}{$\begin{array}{c}\text { Concentration, } \\
\mu \mathrm{g} / \mathrm{mL}\end{array}$} & \multicolumn{2}{c}{$\begin{array}{c}\text { Assay in formulation } \\
\text { (Pantoprazole sodium) }\end{array}$} & $\begin{array}{c}\text { Assay in formulation } \\
\text { (Lansoprazole) }\end{array}$ \\
\cline { 2 - 5 } & $\begin{array}{c}\text { Intra-day } \\
\text { variation, } \\
\text { \%RSD }\end{array}$ & $\begin{array}{c}\text { Inter-day } \\
\text { variation } \\
\text { \%RSD }\end{array}$ & $\begin{array}{c}\text { Intra-day } \\
\text { Variation, } \\
\text { \%RSD }\end{array}$ & $\begin{array}{c}\text { Inter-day } \\
\text { variation, } \\
\% \text { RSD }\end{array}$ \\
\hline 0.0980 & 0.13 & 0.90 & 0.15 & 0.95 \\
0.180 & 0.35 & 0.33 & 0.40 & 0.38 \\
0.80 & 0.40 & 1.60 & 0.45 & 1.70 \\
1.50 & 0.85 & 1.08 & 0.90 & 1.09 \\
3.10 & 0.26 & 0.20 & 0.28 & 0.25 \\
12.5 & 1.65 & 0.70 & 1.70 & 0.75 \\
25 & 0.25 & 1.08 & 0.30 & 1.10 \\
\hline
\end{tabular}




\section{Range and linearity}

The linearity of an analytical method is its ability to elict test results that are directly, or by a well defined mathematical transformation, proportional to the concentration of analyte in samples within a given range. The linearity of the method was observed with in the expected concentration range demonstrating its suitability for analysis. The correlation coefficient $\left(\mathrm{r}^{2}\right)$ was found to be 0.999 and value of intercept was less than 25 of the response of $100 \%$ of the test concentration in all the cases indicating functional linear relationship between the concentration of analyte and area under the peak.

\section{Limits of detection and quantitation}

The detection limit (LOD) is the lowest amount of an analyte in a sample that can be detected, but not necessarily quantitated, under the stated experimental conditions. It may be expressed as a concentration that gives a signal-to-noise ratio of 3:1 (ICH Q2B guidelines, $1996,1997)^{18,19}$. The lower limit of detection for pantoprazole sodium is $2.50 \mathrm{ng} / \mathrm{mL}$ in reference material and formulation and lansoprazole $2.70 \mathrm{ng} / \mathrm{mL}$. Limit of Quantitation (LOQ) is the lowest amount analyte in a sample that can be determined with acceptable precision and accuracy under the stated experimental conditions. A signal-to-noise ratio of 10:1 can be taken as LOQ of the method. The LOQ values were found to be $8.20 \mathrm{ng} / \mathrm{mL}$ for pantoprazole sodium and $9.80 \mathrm{ng} / \mathrm{mL}$ for lansoprazole.

\section{Specificity}

Specificity is the ability to assess unequivocally the analyte in the presence of components that may be expected to be present in the sample matrix. For demonstrating the specificity of the method for drug formulation the drug was spiked and the representative chromatogram. The excipiants used in different formulation products did not interfere with the drug peak and thus, the method is specific for pantoprazole sodium. To further confirm the specificity of the method, UV scans of spiked drug were taken in the range 200-400 $\mathrm{nm}$ and no significant change was found by comparing the absorbance of pure drug and spiked drug at the analytical wavelength of drug.

\section{References}

1. Ritter J M, Lewis L D and Mant T G K, A Textbook of Clinical Pharmacology, $4^{\text {th }}$ Ed., Arnold LTD London, 1999, p. 365.

2. Ewin K J, Goodman \& Gilman's. The Pharmacological Basis of Therapeutics, $10^{\text {th }}$ Ed., McGraw-Hill Inc., London, 2001, p. 1007.

3. Ozaltin N and Kocer A, J Pharm Biomed Anal., 1997, 16, 337-342

4. Sastry C S P, Naidu PY and Murty S S N, Talanta, 1997, 44, 1211-1217.

5. Meyyanathan S N, Raj J R A and Suresh B, Indian Drugs, 1997, 34, 403-406.

6. Moustafa A A M, J Pharm Biomed Anal., 2000, 22, 45-58.

7. Wahbi A A M, Abdel-Razak O, Mahgoub Gazy A A H and Moneeb M S, J Pharm Biomed Anal., 2002, 30, 1133-1142.

8. Salama F, Abasawy N E I, Abdel Razeq S A, Ismail M F and Fouad M M, J Pharm Biomed Anal., 2003, 32, 1019-1027.

9. EI Sherif Z A, Mohamed A O, EI-Bardeicy M G and EI-Tarras M F, Spectroscopy Lett., 2005, 38, 77-93.

10. Renger B J, AOAC. Int., 1993, 76, 7-13.

11. Argekar A P and Kunjir S S, J Planar Chromatogr Mod., 1996, 9, 296-299. 
12. Pandya K K, Mody V D, Satia M C, Modi I A, Modi R I, Chakravarthy B K and Gandhi T P, J Chromatogr B: Biomed Sci Appl., 1997, 693, 199-204.

13. Parfitt K, Editor: Martindale, the complete drug reference, Pharmaceutical Press London, 1999.

14. Gerloff J, Mignot A, Barth H and Heintze K, Eur J Clin Pharmacol., 1996, 50, 293-7.

15. Masatomo M, Tada H and Suzuki T, J Chromatogr B: Analyt Technol Biomed Life Sci., 2004, 804, 389-95.

16. Susheel J V, Lekha M and Ravi T K, Indian J Pharm Sci., 2007, 69(5), 684-686.

17. Zeinab Abdelaziz Et-Sherif, Afaf Osman Mohamad and El-Tarras, Chem Pharmaceut Bull., 2006, 54(6), 814-818.

18. International Conference on the Harmonization of Technical Requirements for the Registration of Pharmaceutical for Human Use (ICH) Q2B, Validation of Analytical Procedures, Methodology, 1996.

19. ICH Q2B: Validation of Analytical Procedures: Methodology, May, 1997.8. 


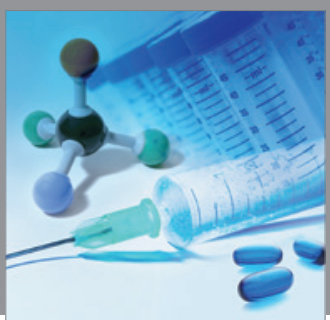

International Journal of

Medicinal Chemistry

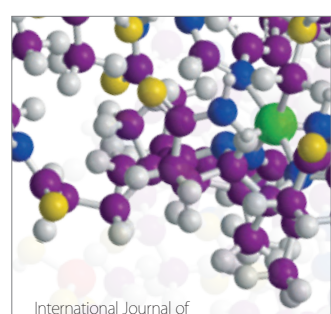

Carbohydrate Chemistry

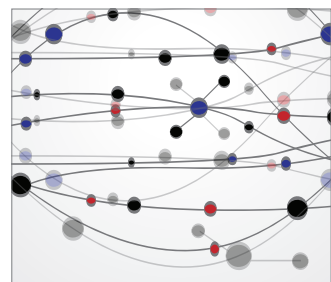

The Scientific World Journal
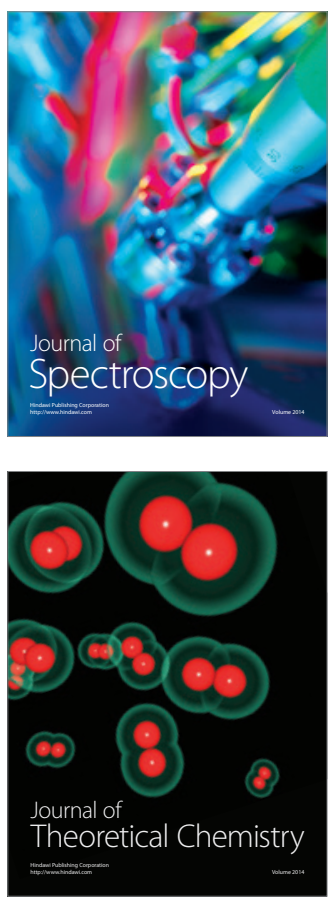
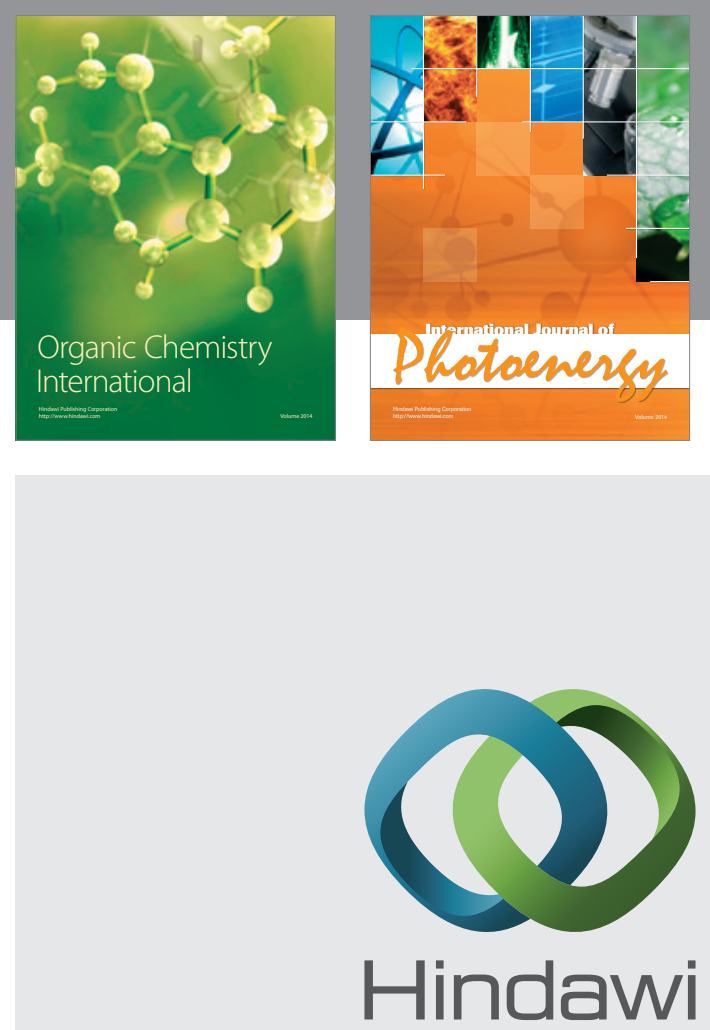

Submit your manuscripts at

http://www.hindawi.com
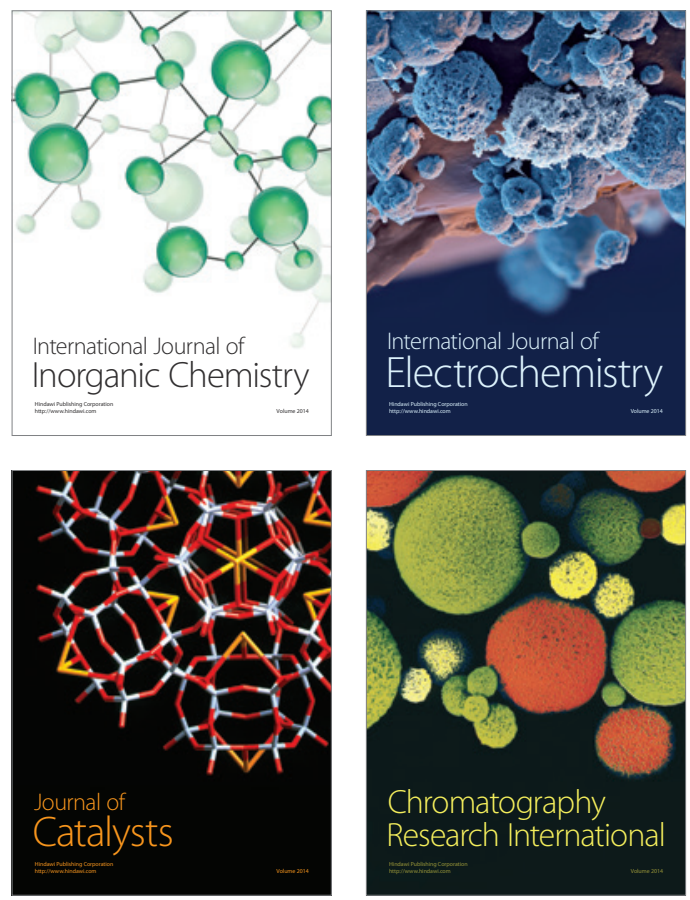
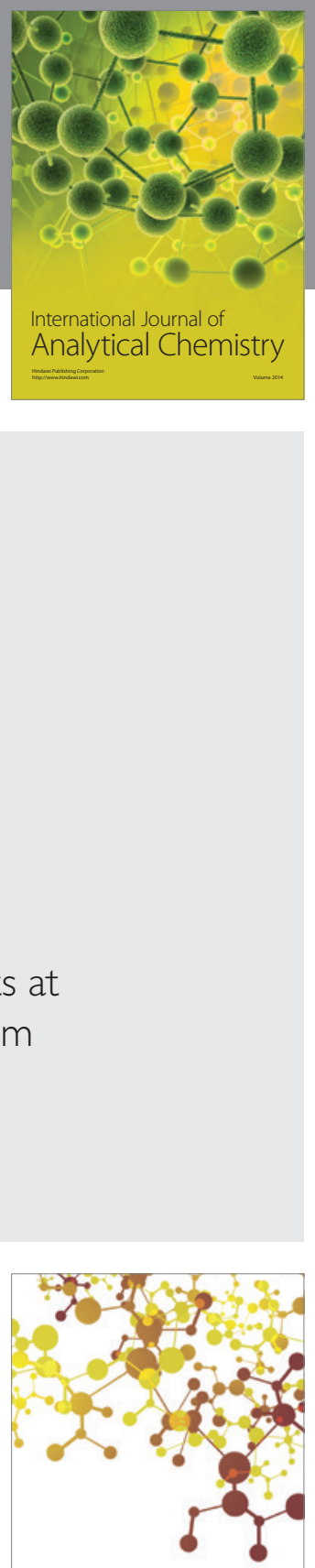

Journal of

Applied Chemistry
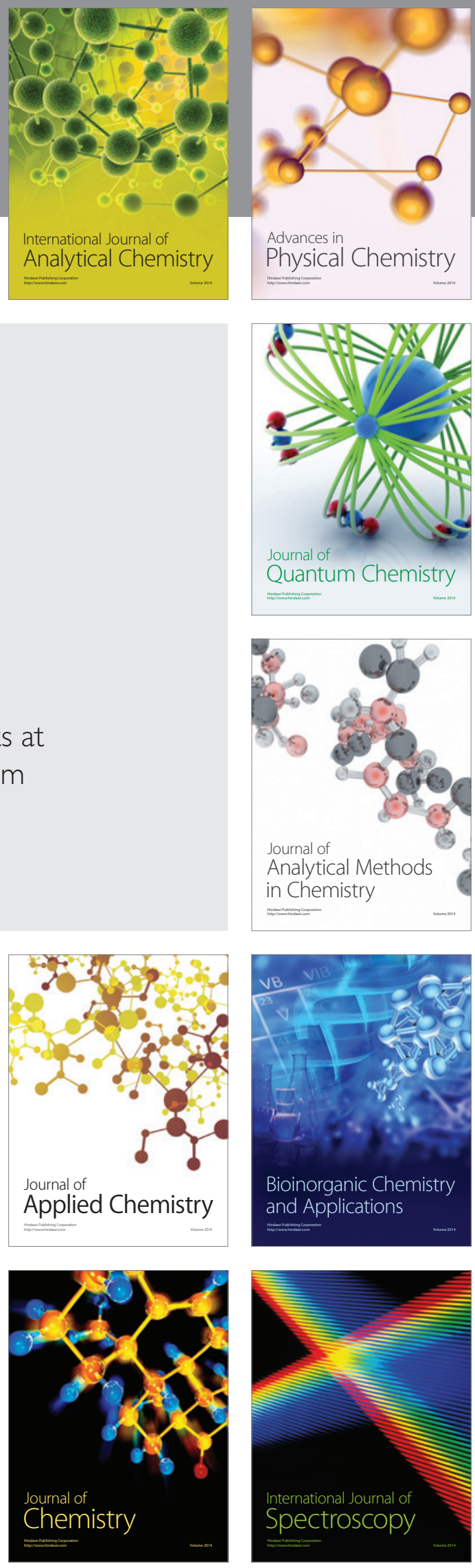